\title{
Parenting and Child Quality on Poor and Nonpoor Families in Cimanuk Watershed
}

\author{
Adinda Widanty * \\ Department of Family and Consumer Sciences, Department of Family and Consumer Sciences, \\ Faculty of Human Ecology, $\quad$ Faculty of Human Ecology, \\ Bogor Agricultutal University Bogor Agricultutal University \\ *Corresponding author: adinda.widanty@gmail.com
}

\begin{abstract}
The objective of this study is to analyze the influence of family characteristics, child characteristics, and parenting quality of poor and nonpoor families toward their quality of children. The design of this research was cross-sectional study conducted at Cimanuk Watershed Area in Indramayu and Garut Sub-District, involving a total of 200 families with 2-5 years old children. The sample consist of 64 poor families and 136 nonpoor families. The analysis results indicate that the length of mother education, the age of children, and parenting quality have significant and positive influence on the quality of children. There is no difference in the quality of children between poor and nonpoor families, eventhough there are significant differences on family size, age of father, length of parental education, family income, and parenting quality done by the parents between poor and nonpoor families.
\end{abstract}

Keywords: parenting, quality of children, poor family, nonpoor family, watershed area

\begin{abstract}
Abstrak
Penelitian ini bertujuan untuk menganalisis pengaruh karakteristik keluarga, karakteristik anak, dan pengasuhan yang dilakukan oleh keluarga miskin dan tidak miskin terhadap kualitas anak. Penelitian ini menggunakan desain cross-sectional yang dilakukan di Daerah Aliran Sungai (DAS) Cimanuk yaitu Kabupaten Garut dan Kabupaten Indramayu dengan sampel sebanyak 200 keluarga yang memiliki anak usia 2-5 tahun. Sampel terdiri dari 64 keluarga miskin dan 136 keluarga tidak miskin. Analisis yang dilakukan meliputi analisis deskriptif dan inferensia diantaranya nilai rata-rata, nilai maksimal minimal, frekuensi, standar deviasi, uji beda independent $\mathrm{T}$ Test, dan uji regresi linear. Hasil analisis menunjukkan bahwa tingkat pendidikan ibu, usia anak, dan pengasuhan memiliki pengaruh positif signifikan terhadap kualitas anak yang dicapai. Tidak ada perbedaan antara kualitas anak pada keluarga miskin dan tidak miskin, namun terlihat adanya perbedaan signifikan pada besar keluarga, usia ayah, tingkat pendidikan orangtua, pendapatan per kapita keluarga, dan pengasuhan secara total yang dilakukan oleh orang tua pada keluarga miskin dan tidak miskin.
\end{abstract}

Kata kunci: pengasuhan, kualitas anak, keluarga miskin, keluarga tidak miskin, daerah aliran sungai 


\section{Introduction}

The quality of human resources is the important aspect to determining the successful of development. As the next generation, young generation are the subject that will determine wether the development would go toward the success or not (Tangdilintin 2008). In order to understand about the quality of yong generation, quality of children becoming the important outcome as a reflection from the quality of the nation and human civilization globally. Quality of children may be representated by the dimensions of growth and child development which indicate the presence of changing process in children (Sunarti 2004). Quality of children become the result from the relationship process between each member of the family along with the family system in it environment. Factors connected with human resources management that aims to improve the qualiy of children are child characteristic which includes child's grade level and family characteristic which includes mother's education and family size (Afriana 2012).

Family is the first environment for children to interact with. From family, children learn to reach their ability to develop through various stimulation within their parenting activity so that the children will achieve their development. Coleman (1988) stated that when parents as family is absent or ot engange with their children there will be lack of social capital, as a result, human resources in family becoming not relevant for children because of the human resources transfer mechanism process will get dysfunctional.

On top of that, human capital investment have an important role in an effort to expand the economy of nation. Based on the data reviewed by Barro (1989) show a positive relationship between human capital resources with the growth rate per capita of real gross domestic bruto (GDP) which means those factors are capable for being controlled then the many countries with high human resources will have higher economic growth. The good quality of human recources basically could determine the productivity of a nation considered as very important resources in terms of its economic growth.

Children being perceived to be a happiness and good fortune in the majority of family in Indonesia (koentjaraningrat 2007). More than 90 percent of families in research conducted by Hartoyo (1998) agree that children give psychological values like strengthen marriage bond, as a holy purpose of marriage, and completing someone as a man or woman in the family. One of the human capital investment is investment in children (Mayer, 2002; Conger, et al. 2010; Becker, 1975). Parent investment in children is one of the theory model that influence the relationship between family economic conditions with children development. Parent investment in children consist of money value as material aspect and time allocation as non material aspect. Investment in the form of time for children is important thing in term of quality of human resources development, especially children as the next productive adult in the future. Investment in the form of time also as a mechanism of the economic status derived from generation to generation (Guryan, et al. 2008). Investment activity in the form of parent time allocation reflected in raising children, especially by mother, through caring depicted in parenting practice to achieve optimal competence in children so that it will produce high quality children (Bryant dan Zick, 2006). 
Parenting quality is application of parenting practice doing by parents, mother, or another main caregiver toward children. Parenting quality including feeding practice and psychosocial parenting practice. Those activity include preparing and giving meals to children, reading story, playing with children, giving age-appropriate toys, teaching, and take children for a walk outside their home environment. Those activities reflect the quality of time allocation that invest by parent or children caregiver toward children that important in term of child development to improve the quality of children (Guryan et al. 2008; Mincher dan Polacheck, 1974). Difficult condition like poverty, could influence the act of investment by parents toward their children. It because on poor group, they focus using resources they have on daily basic needs they are lacking of. Even, Gordon et. al on UNICEF publication (2003) stated that poverty had an impact on various aspect of life and threatened the continuation of child development.

Surachman dan Hartoyo (2012) found that family with high social economic condition have better investment act toward their children. Non poor family have higher income compared with poor family (Bahri dan Hartoyo 2013). Hastuti (2015) also stated that well established couple, economically stable, will have greater chance to engange relatively better parenting practice compared with economically unstable couple. Previous empirical evidence study found that the effects of poverty on children development affected by family behavior. Low income family and family with poverty often have low access to education and it will decrease family ability to provide environment with responsive stimulation for children (Engle dan Black, 2008).

High income family will devote better rosources they have to improve quality of children. Devoting resources by family distributed in form of child investment divided into material investment consist of family expenditure for children, and non material investment consist of time allocation parent-children communication, and parenting quality (Rahmiati dan Puspitawati 2013). Parenting quality is a technique or the way parents doing their parenting practice including feeding practice, healthy lifestyle, academic practice, social-emotion practice, and moral character with discipline (Hastuti 2015). Based on this, can be defined in general that parenting is part of investment in children with quality of practice pattern that show the relationship in certain aspects and follow children needs in order to have normal and independent life which would be different between poor and non poor families.

According to Caceres (2004), one of the factors that affect the success of education attainment and children economic condition in a future relate with the quality of children is the type of environment where the children live. According to Mardiya (2013) children have their own potential in order to reach their development. In that case, beside parenting practice and socioeconomic condition, environment becoming one of important thing to provide children building their quality. Environment means events, the situation and conditions outside individual that affecting children or individual development directly or indirectly. Environment consist of physical and social environment. Physical environment menas everything physical around individual like houses, rice fields, the ground, water, and so forth. Physical environment also known as natural environment. The differences of natural environment will also give different imoact for individual. As an example, mountainous regions will give different impact on individual living there compared with individual licving in coastal regions and this also occurred in watershed area. 
Cimanuk watershed is one of the main watershed of 40 watershed and one of the main water resource support in West Java regions, choosen as the environment which the study being conducted. It located on the east of West Java Region with Garut Regency as its upstream and Indramayu Regency as its downstream (Balitbang Deptan 2006). West Java Central Bureau Statistics (2015) mentioned that Garut Regency has 12.47 percent of poor family in 2014. The poverty becoming one of health problem in Garut Regency like malnutrition. Data from study conducted by Aryastami et al. (2012) showed that the prevalence of malnutrition in one of the sub-district considered high with the number of 5.7 compared with prevalence of West Java in general with the number of 3.7 even Indonesia with the number 5.4 per 100 toddlers. Environment and sanitation, family behavior (hygiene and children vaccination in this case), and health services becoming related factors causing problems in Garut Regency. This data further strengthened by the results of Purnama et al. (2012) study that food secutity, parenting practice and its quality, health services in environment becoming factors related with problem happened in Garut Regency. Beside Garut Regency, Indramayu Regency, downstream area of Cimanuk watershed has public welfare level that just reach 38.6 percent while the remaining of 61.4 percent still on unprosperous stage condition (BAPPEDA 2016).

Based on those facts, this study will define numerous things that will be research purpose like: (1) identify parenting quality and quality of children on poor and nonpoor family in watershed area; (2) analyze the family characteristics, child characteristics parenting quality, and the quality of children in Cimanuk watershed area; and (3) Analyze the influence of family characteristics like parents age, parents education, family size, and family income per capita, children characteristics like children's age and parenting practice quality toward quality of children on families in Cimanuk Watershed are.

\section{Methods}

This research is part of the joint research with the theme "Livelihood Strategy and Family Poverty Dynamics in Cimanuk Watershed". The population of this study are families with children aged 2-5 years old who live around the Cimanuk Watershed, both upstream and downstream, namely in Garut and Indramayu. This research use crosssectional study design. The research location was conducted in Cimanuk Watershed which was chosen purposely by considering that Cimanuk Watershed is the second longest river becoming one of the main source of water resources in West Java (Susetyaningsih 2012). Selection of District and Village chosen purposely (deliberate) with consideration of district and village trough by Cimanuk River. Sampling of each village is done purposely with consideration of having children aged under 2-5 years old. From each village, 50 families were obtained so that from the five villages, there were 200 families. Specifically for this study, the analyzed samples were divided based on the criteria of the 2015 BPS Poverty Line with per ca pita income as a benchmark, being a poor family of 64 families and non-poor families totaling 136 families. Examples of related data were obtained through residential approach and in-depth interviews.

The data collected are primary and secondary data. Secondary data were obtained from related institutions and various literatures such as BPS data, sub-district 
data, and population data from villages including village demographic data and poverty line viewed from per capita income. Primary data were obtained through interview technique to mother using questionnaires, including: (1) family characteristics (education, age, family size, family income, and occupation); (2) characteristics of the child (age); (3) parenting (seen from parenting and psychosocial care); And (4) the quality of the child (seen from the child's cognitive and social dimensions based on direct observation of the child). Measurements were made using an adapted and modified questionnaire from Hastuti (2015) for feeding and HOME Inventory (Caldwell and Bradley 1984 in Salimar et al. 2011) questionnaires for psychosocial care. Feeding questionnaires each with a Cronbach Alpha value of 0.667 and HOME Inventory Questionnaire for psychosocial care consisted of 45 point statements for groups of 2-3 year olds and 55 items for groups of children aged 3-6 years. Child Quality consisting of cognitive dimensions was measured using an adaptation questionnaire and modification of the Bina Keluarga Balita (BKB) questionnaire by Salimar et al. (2011) for children aged 2-3 years, 3-4 years, and 4-5 years with each value of cronbach alpha $0.606 ; 0.705$; and 0.736 . Beside that, social dimensions for the same age measured by Vineland Social Maturity Scale (VSMS) questionnaire with cronbach alpha value of 0.730 for children aged 2-3 years, 0.631 for children aged 3-4 years, and 0.602 for children Age 4-5 years.

The data that has been obtained is then processed using Statistical Package for Social Science (SPSS) for Windows and Microsoft Excel. Data processing includes the process of editing, coding, scoring, entrying, cleaning, and analyzing. Data analysis was done descriptive and inferential statistic through descriptive test, correlation test, and multiple linear regression test.

The categorization range is derived from the question value of each dimension of the quantized variable and then summed and converted in the index form so that the minimum value 0 and 100 are obtained. The index is calculated by the formula:

Index

$$
=\frac{\text { Actual Value }- \text { Minimum Value }}{\text { Maximum Value }- \text { Minimum Value }} \times 100
$$

Information:

Index

$=$ value scale from 0 to 100

Actual value

$=$ value obtained by respondent

Maximum value

$=$ highest value that should be obtained by respondent

Minimum value

$=$ lowest value that should be obtained by respondent

After that, the achieved index score is entered into the class category. Scores are grouped into three categories, namely low, sufficient, and good. Furthermore, it takes a class interval to determine the cut off variable. The class interval formula is as follows (Puspitawati and Herawati 2013):

$$
\text { Class Interval }=\frac{(100-0)}{3}=33.33
$$

Cut offs obtained for categorization are as follows :

1. Less: $0.00-33.33$

2. Enough: $33.34-66.67$

3. Good: $66.68-100$ 


\section{Results}

\section{Family Characteristics and Child Characteristics}

The characteristics of the family in the study include the family size, the age of father and mother, the education level of father and mother, the work of the father and mother, and the average income per capita of the family (total income divided by family), for the characteristics of the child under study is the age of the child. (This explanation should already be submitted in the introduction section, on the part of the results can directly present the data obtained). All descriptive statistics can be presented in the table to make it easier to understand

\section{Family Size}

The family size in this study represents the total number of family members (including breadwinners) who are still dependent on the head of the household, who live in one house by example. BKKBN classified the family into three, namely: small family, medium family, and extended family. Small families are families with no more than four members. The medium family is having a membership of five to seven people while the extended family has more than seven members. Descriptive test results indicate that half of the total sample families of both poor and non-poor families are included in small families (54\%) with an average of four family members. There is a marked difference $(\mathrm{p}<0.01)$ between large poor families compared with non-poor families with a greater share of poor families than non-poor families. More than half $(56.2 \%)$ of poor households are in the moderate category whereas in non-poor families, more than half $(64.7 \%)$ are in the large category of small families. In poor families, the minimum family size of the sample is 3 people and maximal family 11 people with an average score of 5.58. In non-poor families, the minimum sample family is 3 people and maximally a family of 8 people with an average score of 4.35 .

\section{Age}

More than half of the sample families in this study had an average age of fathers and mothers classified as early adulthood (22-40 years). There was a marked difference ( $p$ $<0.05$ ) between the father's age in poor families and non-poor families with an average father's age in the larger poor families. Descriptive test results on the characteristics of children is the age of children shows the average age of children studied is 45.23 months or are in the age range of 3-4 years.

\section{Education and Income per Capita}

The sample family in this study both father and mother completed primary school level but did not complete the junior high school level with an average length of education for 8.25 years in the father and 7.98 years in the mother. Different test results show a significant difference between the education level of the father and mother in poor and non-poor families. The average level of education of father and mother in poor families is lower than that of non-poor families. A marked difference was also shown in the per capita income variable with the average per capita income of larger families in non-poor families. 


\section{Work}

In non-poor families, dominant duties of father are as lower-middle entrepreneurs $(33.8 \%)$ whereas in poor families, much of the work is farm labor $(29.7 \%)$. In mothers' working variables in poor families, more than two-thirds $(70.3 \%)$ of mothers in the sample family did not work as well as in non-poor families, more than half of the mothers $(65.4 \%)$ in the sample family also did not work.

\section{Parenting}

Parenting is done on the practice of parenting include the care of nutrition and health and psychosocial care. In children under five years in this study, care in nutrition and health aspects is seen from the feeding, while the nurturing on the social, emotional, academic, and moral aspects is seen from the parent's psychosocial care in children (Hastuti 2015). Growth depends on the amount and type of food the child eats. The relationship between food and growth is a major concern for nutritionists, however food intake is not the single most important aspect of growth but is also influenced by the fact that feeding or feeding practices, especially at an early age, are a social process. Feeding involves interaction between mother and child so this will most likely also affect child development (Myers 1993).

The results showed that in the dimensions of feeding in poor families, half $(50 \%)$ of the sample households were in the category of adequate nursing while in nonpoor families, more than two-thirds $(77.9 \%)$ of sample households did feeding practices on good category. Feeding at poor families has a minimum score of 30.0 and a maximum of 100 with an average score already included in either category (67.89). In non-poor families, the minimum nursing scores were achieved at 40.0 and a maximum of 100 with the mean scores also falling into either category (77.02) even above the average value of feeding in poor families. Overall, the practice of upbringing conducted by sample families in the Cimanuk watershed in this study was more than half $(68.5 \%)$ in the good category with a mean value of 74.10. There was a marked difference ( $p$ $<0.01$ ) of the average meal parenting scores in poor families and non-poor families with an average non-poor family eating scores higher than in poor families.

The results also show that the psychosocial care dimension in the poor family, half $(50 \%)$ of the sample family is in the category of sufficient psychosocial care and the other half is in the good category, no sample families are in the low category whereas in the non-poor families, More than half $(63.2 \%)$ of the sample households practiced psychosocial care in either category. Psychosocial care in poor families has a minimum score of 44.27 and a maximum of 86.29 with an average score already included in either category (66.78). In non-poor families a minimum psychosocial care score of 42.09 and a maximum of 95.83 with an average score of 69.37 and greater than average psychosocial care for poor families. Overall, the practice of psychosocial care carried out by sample households in the Cimanuk watershed in this study was more than half $(61.5 \%)$ in the good category with a mean score of 68.54 . There was a marked difference $(\mathrm{p}<0.1)$ between the mean score of psychosocial care in poor and non-poor families, with higher mean scores for non-poor families.

Viewed from the total parenting dimensions of the poor households presented in Table 1, half (50\%) of the sample households are in adequate care category whereas in non-poor families, almost all $(80.1 \%)$ sample households practice in good category care 
The average value of care was 71.32. The care of poor families has a minimum score of 46.24 and a maximum of 86.31 with an average score already included in either category (67.33).

Table 1 Sample distribution based on total parenting practices and poverty status

\begin{tabular}{lllllll}
\hline \multirow{2}{*}{ Parenting } & & Poor & \multicolumn{2}{c}{ Non Poor } & \multicolumn{2}{c}{ Total } \\
& $\mathrm{n}$ & $\%$ & $\mathrm{n}$ & $\%$ & $\mathrm{n}$ & $\%$ \\
\hline Less & 0 & 0 & 0 & 0.0 & 0 & 0.0 \\
Fair & 32 & 50.0 & 27 & 19.9 & 59 & 29.5 \\
Good & 32 & 50.0 & 109 & 80.1 & 141 & 70.5 \\
\hline Total & 64 & 100.0 & 136 & 100.0 & 200 & 100.0 \\
\hline
\end{tabular}

In non-poor families, the minimum nurse scores were achieved at 47.68 and a maximum of 95.42 with a mean score that has also fallen into good category (73.20) and greater than the value of care for poor families. In general and overall, the results in Table 3 show that the practice of care carried out by sample households in the Cimanuk watershed in this study was more than two-thirds (70.5\%) in the good category. This indicates that more than half of mothers as caregivers in the family in this Cimanuk watershed have done good parenting practices for their children and there are no example families caring for children falling into the low category. Different tests using independent T-test showed significant differences $(\mathrm{p}<0.01)$ between feeding, psychosocial care, and total care for poor families and non-poor families with an average meal parenting score, psychosocial care, and more total care High in non-poor families.

\section{Quality of Children}

The quality of children is a very important outcome as a reflection of the quality of the nation and the quality of human civilization globally. The child's quality or child's degree of dependability can be represented in terms of the growth and developmental dimensions of the child that indicating a change process (Sunarti 2004). In this study, the quality of children is represented by aspects of development measured in terms of cognitive and social.

The results showed that the quality of children in the cognitive dimension in poor families, more than half $(57.8 \%)$ of children in sample families had achieved the quality of cognitive dimensions in both categories as well as in non-poor families, more than half $(64.8 \%)$ of children in the family The example has reached the quality of the cognitive dimension in either category. The quality of the child the cognitive dimension of the poor family has a minimum score of 20.83 and a maximum of 100 with an average score of 67.74, while the non-poor families have a minimum score of 35.7 and a maximum of 96.0 with an average score of 68.83 . Overall, the quality of the cognitive dimensions achieved by children in sample families in the Cimanuk watershed in this study was more than half $(62.5 \%)$ in the good category with a mean score of 68.47 .

The quality of children in the social dimension of poor families, more than twothirds $(75 \%)$ of children in sample households have achieved the quality of social dimension in both categories, as well as in non-poor families ie more than two-thirds (76.5\%) of children Sample families have achieved the quality of social dimensions in either category. Child quality of social dimension to poor family has minimum score of 12.5 and maximum reached 100 with average value 76.68 , whereas in non-poor families 
have a minimum score of 20.0 and maximum reached 100 with an average score of 75.85. Overall, the quality of the social dimension achieved by the children in the sample households in the Cimanuk watershed in this study was more than half (76\%) in the good category (76.11) but the mean score indicated that the mean value of the child's social dimension quality In poor families in this study is also higher than the achievement of social dimensions of children in non-poor families.

Viewed from the total child quality dimensions of the poor families in Table 2, the children in the sample family have achieved good category quality, as many as twothirds $(67.2 \%)$ of children in the sample family have achieved good category quality with the remainder in adequate categories $(31.2 \%)$ And low (1.6\%) with a minimum value of 32.58 and a maximum score of 97.92 with an average score of 72.21 , while in non-poor families, although the quality of children achieved is included in either category, there are also two-thirds $(68.4 \%)$ and Which is in sufficient category there are 31.6 percent, but there are no children in the sample family whose total quality achievement is included in the low category with a minimum value of 35.42 and the maximum score reached 97.92 with an average score of 72.34. In general and overall, the results in Table 6 show that based on the calculation of child quality index score, the quality achieved by the children in the sample family in the Cimanuk watershed in this study was more than two thirds $(68.0 \%)$ in the good category, the remainder being Enough category $(31.5 \%)$ and low $(0.5 \%)$ with a mean score of 72.30 . This suggests that more than two-thirds of the children in families in this Cimanuk watershed have been able to work on basic activities that determine the cognitive and social abilities that should be able to be performed by children at the appropriate age but there must be continuous stimulation And continues to be done by parents to children considering the existence of families with children whose quality is in the low category. In the different test using independent $\mathrm{T}$-test independent test, the results did not show any difference in the quality of the child, either the cognitive or social dimension and both in the poor and non-poor families as shown in Table 2.

Table 2 Distribution of examples based on the quality of children achieved and poverty status

\begin{tabular}{lcccccc}
\hline \multirow{2}{*}{ Quality of Children } & \multicolumn{2}{c}{ Poor } & \multicolumn{2}{c}{ Non Poor } & \multicolumn{2}{c}{ Total } \\
& $\mathrm{n}$ & $\%$ & $\mathrm{n}$ & $\%$ & $\mathrm{n}$ & $\%$ \\
\hline Less & 1 & 1.6 & 0 & 0.0 & 1 & 0.5 \\
Fair & 20 & 31.2 & 43 & 31.6 & 63 & 31.5 \\
Good & 43 & 67.2 & 93 & 68.4 & 136 & 68.0 \\
\hline Total & 64 & 100.0 & 136 & 100.0 & 200 & 100.0 \\
\hline
\end{tabular}

\section{Factors Affecting the Quality of Children}

Based on the results of multiple linear regression test in Table 3, it is known that maternal education, child age, and parenting have a positive effect on the quality of children. This means that in the group of mothers with higher education have children of under five with higher quality, in the higher age group of children under five have higher quality, and in the group of families with better parenting will have a quality child Also higher but in this study was poverty status was not proven to give a significant positive effect on the quality of children achieved. 
Table 3 Multiple linear regression test results on factors that affect the quality of children

\begin{tabular}{|c|c|c|c|c|}
\hline \multirow{2}{*}{ Variable } & \multicolumn{2}{|c|}{ Unstardardized Coefficient } & \multirow{2}{*}{$\begin{array}{l}\begin{array}{l}\text { Stardardized } \\
\text { Coefficient }\end{array} \\
\text { Beta }\end{array}$} & \multirow{2}{*}{ Sig. } \\
\hline & $B$ & Deviation & & \\
\hline Constant & 16.704 & 10.664 & & 0.119 \\
\hline $\begin{array}{l}\text { Poverty Status }(0=\text { not poor, } \\
1=\text { poor })\end{array}$ & 2.983 & 2.420 & 0.090 & 0.219 \\
\hline $\begin{array}{l}\text { Region }(0=\text { downstream, } 1 \\
=\text { upstream })\end{array}$ & 0.030 & 2.028 & 0.001 & 0.988 \\
\hline Gender & -2.697 & 1.792 & -0.086 & 0.137 \\
\hline Maternal education (years) & 1.073 & 0.340 & 0.196 & $0.002 * * *$ \\
\hline Mother age (years) & -0.048 & 0.192 & -0.019 & 0.801 \\
\hline Family size (persons) & -0.070 & 0.904 & -0.006 & 0.938 \\
\hline Income per capita IDR) & $8.855 \times 10^{-7}$ & 0.000 & 0.039 & 0.560 \\
\hline Child Age (months) & 0.655 & 0.072 & 0.522 & $0.000 * * *$ \\
\hline Parenting & 0.249 & 0.110 & 0.152 & $0.025 * *$ \\
\hline $\boldsymbol{F}$ & & & & 14.571 \\
\hline R square & & & & 0.379 \\
\hline Adj R square & & & & 0.353 \\
\hline Sig. & & & & 0.000 \\
\hline
\end{tabular}

Information $* *$ significant at $\mathrm{p}$-value $<0.05, * * *$ significant at $\mathrm{p}$-value $<0.01$

Overall, the variables in this study affect the quality of children by 35.3 percent in multiple linear regression models with high significance and the remaining 64.7 percent influenced by other variables not examined in this study.

\section{Discussion}

The result of the research shows that there are differences of characteristics of poor and non-poor families. The results also indicate the types of occupations that dominate in poor families of some types of jobs, such as non-employment, civil servants, farm workers, farmers, other laborers, lower-middle entrepreneurs, highincome entrepreneurs (employers), private and other employees, Are farm laborers. In line with Todaro and Smith (2006) that in developing countries, as many as two-thirds of poor families work as farm laborers or small farmers. Low income with high dependents, causing economic problems in the family causing poverty. Poor households also tend to have more family members that cause family inhibition in their efforts to improve human resources (BPS 2012). In addition, BPS (2012) also mentions that poor households tend to have minimal expertise and knowledge due to the low educational attainment of family members resulting in low productivity.

Different test results also show a difference from the average score of total parenting index between poor and non-poor families with a lower parenting scores score in poor families. Poverty is often the cause of the lack of stimulation given by parents to children due to the limitations they have. This is in line with the research conducted on the family of skipper and family of fishermen workers who also showed differences, especially in terms of the quality of care between two types of poor and non-poor families (Hastuti 2015). Hastuti (2015) also stated that an established, economically 
stable partner would have more opportunities to provide better relative care than those who are not self-sufficient and weak in economic capacity. The results showed that there was no significant difference between the quality of children in poor and non-poor families. This is not in line with Soetjiningsih's (1995) study which states that low income families still have not prioritized improving the quality of life of children, this is possible because of certain perceptions of parents to children. The family investment model explains that it is possible that caregivers are investing more time or material to children for educational resources, when caregivers perceive that their children are academically smart so that this will affect the quality of children in poor families even in poverty (Engel and Black 2008) .

In the regression test, the results of the tests in the study showed that the level of mother education, child age, and nursing have a significant effect on the quality of children. In line with findings Leibowitz (1982) which indicates that the level of education of the mother significantly related to the development of IQ of children due to the increasing insight and knowledge possessed. This is also explained by De Tray (1974) that the involvement of fathers in the care of children tends to be less than mothers because of the factor of working hours. The difference in allocations by husbands and wives in carrying out parenting practices supports the assumption about the timing of children's service production that women have more intensive time for children than men.

The quality of children affected by parental education can also be explained from findings about parenting practices that have significant relationship with maternal and maternal education (Salimar et al. 2011; Maidah 2014). In line with Hill and Stafford's (1974) study using national data from a University of Michigan research center that found that women with high social status spent two to three times the upbringing for pre-school age children compared with women with low socioeconomic status . Parents with longer education tend to have better knowledge. In addition, if the mother has a high knowledge then will be more active in seeking information to improve knowledge and skills in child care (Hastuti et al., 2010).

Regression test results found that the age of children affect the quality of children. This is in accordance with the theory of child development that goes along with age. This means that the child's progress will increase with age (MOH 2000). Parenting has a significant positive effect on the quality of children in line with Hastuti (2008) research that the quality of children is directly affected by the interaction and relationship between mother and child consisting of the quality of care and stimulation provided by the mother to the child. Parenting is a mother-to-child care practice in which there is stimulation and interaction between mother and child. Based on the information of respondents directly obtained when the research, that many of the respondents who practice feeding with while inviting children to tell stories, play, and some even feed the child while stimulating the child in terms of learning as while learning to write, respondents also do stimulation in children Which is seen from the practice of psychosocial care.

Regression test results show that in this study, poverty is not proven to give a real difference and a significant influence on the quality of children achieved. The cause of this happening is because the achievement of the quality of the higher social dimension in children in poor family is seen from the mean value. This is related to the stimulation of social development gained in poor families who are also good. It will be 
further described. Myers (1993) mentions that downgrading is based on much literature on child development, there are some important statements in understanding and building early childhood education and care programs, one of which is that the social and cognitive development of children is closely linked to cell growth and the development of relationships between neurons On their brains. Therefore, health and nutrition conditions that damage the brain even when before the child is born, will interfere with its development. However, the child is a very remarkably resilient individual or very resilient, especially in early ages. Children have certain mechanisms that can help themselves to develop. The development of a child may be delayed, developmental damage may also occur as a result of problems when birth or an unsupported after-birth environment (such as poverty), except for very severe and severe problems or damage such as prolonged malnutrition, Still have the potential to re-develop normally. Therefore parents should be aware of the fact that children suffering from poor health or poor neighborhoods will not automatically develop their development.

Children, especially at an early age, in addition to needing nutritious food, decent housing, health care and services, also need a stimulant base for their psychological and social development that is the need for love and affection, good interaction in the form of stimulation and reaction to the child, the environment Consistent in parenting, and the need for exploration and finding something by yourself (Myers 1993).

In this study, upstream Cimanuk watersheds with many more poor families were not proven to differ and influence the low quality of children. This is possible because despite experiencing poverty, the sample family still has a way to ensure that children still receive feeding and stimulation while still in a state of limitations and most importantly still meet the basic needs of stimulation for psychological and social development which then gives good results for Quality of the child to the family. Based on observations when the research also can be seen that quite a lot of poor families are more open in teaching independence in their children so that children do not hesitate when exploring, exploring, and finding something in the environment itself.

Another factor that may contribute is the likelihood of influencing other variables important to the quality of children today, but not further investigated in this study. These variables are, for example, the effect of media exposure on children under five, the presence of peer groups owned by toddlers, both peer groups in school and peer groups in the home environment, and the school environment is broadly like school quality, teacher quality, and school activities Or learning activities of children under five when in school.

Family size and family incomes also did not have a significant effect on the quality of children, not in line with Jones et al. (2002) that the age of the mother when married and the family is related to the quality of the child in the family. Based on the results of the relationship test in this study also obtained the result that there is no significant relationship between large variables of family and income with the quality of children achieved. In addition, it is predicted to occur also because in research conducted, the quality is only seen influenced by maternal care and does not measure the care provided by the father. Not possible, the parenting performed by the father contributes to the impact on the quality of children achieved and affect the results of other variables. In addition, in general the existence of variables that have no effect such 
as poverty status, region, mother's age, family size, income per capita, and gender of the child is possible because the model in research assume that all variables directly influence without seeing the possibility of variables between or Indirect variable so that the visible effect is not significant.

Regression test results also show that the model of this study investigated that the quality of children can be explained by 35.3 percent through the factors studied. There are many other factors, at 64.7 percent, that determine the quality of children not seen in this study. This study also still has limitations in some aspects, one of them in the selection of sampling methods. This study uses purposive method so that the result can not describe the population as a whole. In addition, because child development, which represents the quality of children in this study, is something that is closely related to growth. Therefore, nutritional status and health status are possible to provide better results and more complete discussion of the quality of research achieved by children.

\section{Conclusion and Suggestion}

\section{Conclusion}

There is a difference in the level of parent education, fatherhood, family size, per capita income, and care between poor families and non-poor families with lower average outcomes in poor families except for large families and father ages. Both poor and non-poor families have done good parenting to children. This is demonstrated by both parenting and psychosocial care scores on both types of households that fall into the high category. So also with the quality of children achieved in two types of families. The influence test (regression) indicates that mother's education level, child age, and nursing have an effect on to the quality of the child. The higher the level of education taken by the mother, the higher the age of the child, and the better parenting performed by the mother to the child then the quality of the child achieved is also better.

\section{Suggestion}

Based on the results of the study, mothers with children under five are expected to enrich knowledge and insight about toddlers good knowledge about eating and psychosocial child. In addition, it is also important for the government or related agencies in the family field to re-utilize, activate and supervise programs for early childhood, such as the Bina Keluarga Todita (BKB) program, actively as a container of knowledge for parents of toddlers. The government is also expected to be able to actively support the provision of counseling and knowledge to families in caring for children, especially children under five, such as giving knowledge about giving toys from simple tools to children without having to spend funds such as utilizing existing tools as a stimulation for Children, especially in poor families. The result that the quality of children in poor families is better than the quality of children in non-poor families can be input so that further research can be investigated further about the factors that cause it scientifically, in addition to the possible factors that have been reviewed in this study.

\section{References}

Afriana, H. (2012). Analisis Investasi dan Kualitas Anak pada Keluarga Nelayan di Kabupaten Sukabumi [skripsi]. Bogor (ID): Instit ut Pertanian Bogor 
Aryastami, N.K., Prahastuti, B.S., Budisuari, M.A. (2012). Analisis Situasi dan Upaya Perbaikan Gizi Balita di Tingkat Kabupaten: Studi Kasus Kabupaten Garut Tahun 2008. Buletin Penelitian Sistem Kesehatan. 15(3): 232-239

[BAPPEDA] Badan Perencanaan Pembangunan Daerah Indramayu. (2016). Rencana Pembangunan Jangka Menengah Daerah Indramayu [internet]. [diunduh 18 Maret 2016]; 1-45. Tersedia pada: http://www.bapeda.indramayukab.go.id/data/rpjmd/BAB-II-RPJMD.pdf

[Balitbang Deptan] Badan Penelitian dan Pengembangan Pertanian Departemen Pertanian. (2006). Pengelolaan Sumber Daya Lahan dan Air di Indonesia. Jakarta (ID): Balitbang Departemen Pertanian

[BPS] Badan Pusat Statistik. (2015). Jawa Barat dalam Angka. Badan Pusat Statistik Provinsi Jawa Barat.

(2012). Analisis Data Kemiskinan Berdasarkan Data Pendataan Program Perlindungan Sosial (PPLS) 2011. Jakarta (ID): Badan Pusat Statistik.

.( 2014). Kemiskinan di Jawa Barat dalam angka tahun 2014.

Melalui online: www.bps.go.id

Bahri, N., Hartoyo. (2013). Perilaku Investasi Anak pada Keluarga Miskin dan Tidak Miskin. Jur. Ilm. Kel. \& Kons. 6(3): 190-198

Barro, R.J. (1989). Economic Growth in a Cross Section of Countries. E-journal of National Bureau of Economic Research [internet]. [diunduh 14 Maret 2016]; 149. Tersedia pada: http://www.nber.org/papers/w3120.pdf

Becker, G.S. (1975). Investment in Human Capital: Effects of Earnings. Di dalam: Becker GS. Human Capital: A Theoritical and Empirical Analysis, $2^{\text {nd }}$ Ed. National Bureau of Economic Research.

Bryant, W.K, Zink, C.D. (2006). The Economic Organization of the Household, Second Edition. New York (US): Cambridge Univ Pr.

Caceres, J. (2004). Impact of family size on investment in child quality: Multiple births as a natural experimental. E-journal of Applied Microeconomics, 1-42. Diambil dari http://www.tinbergen.nl/cost/london/ caceres.pdf. [diunduh 28 Desember 2015].

Coleman, J.S. (1988). Organizations and Institutions: Sociological and Economic Approaches to the Analysis of Social Structure. Chicago (US): University of Chicago Press

Conger, R.D., Conger, K.J., Martin, M.J. (2010). Socioeconomic Status, Family Process, and Individual Development. Journal Marriage Family, 72(3):685-704.

Departemen Kesehatan RI. (2000). Pedoman Deteksi Dini Tumbuh Kembang Balita, Direktorat Kesehatan Keluarga, Direktorat Jenderal Kesehatan Masyarakat, Departemen Kesehatan, Jakarta.

De Tray, D.N. (1974). Child Quality and The Demand for Children. E-journal of National Bureau of Economic Research [internet]. [diunduh 28 Desember 2015]; 91-119. Tersedia pada: http://www.nber.org/chapters/c2964

[Dirhut KSA] Direktorat Kehutanan dan Konservasi Sumberdaya Air. (2005). Kajian Model Pengelolaan Daerah Aliran Sungai (DAS) Terpadu [internet]. [diunduh 2016 Mar 17]. Tersedia pada:

http://www.bappenas.go.id/files/2513/4986/1927/17kajian-model-pengelolaandaerah-aliran-sungai-das-terpadu_20081123185136_1261_16.pdf. 
Engle, P.L., Black, M.M. (2008). The Effect of Poverty on Child Development and Educational Outcomes. Annals of the New York Academy of Sciences, 1136(2): 43-56.

Gordon, D., Shailen, N., Cristina, P., Simon, P., Peter, T. (2013). Child Poverty in Developing World. Bristol (GB): UNICEF

Guryan, J., Hurst, E., Kearney, M. (2008). Parental Education and Parental Time with Children. Journal of Economic Perspective, American Economic Association, 22(3): 23-46

Hartoyo. (1998). Investment in children: study of rural families in Indonesia. [Disertasi]. Blacksburg (US): Virginia Tech University.

Hartoyo, Hastuti, D. (2004). Perilaku Investasi pada Anak Keluarga Nelayan dan Implikasinya terhadap pengentasan kemiskinan. Jurusan Gizi Masyarakat dan Sumberdaya Keluarga, Fakultas Pertanian, Institut Pertanian Bogor. Bogor (ID): IPB

Hastuti, D. (2015). Pengasuhan: Teori, Prinsip, dan Aplikasinya di Indonesia. Bogor (ID): IPB Press

Hastuti, D., Hidayat, S., Megawangi, R., Guhardja, S., Patmonodewo, S. (2008). Karakteristik Keluarga, Interaksi Ibu dan Anak, dan Pengasuhan serta Pengaruhnya pada Tumbuh Kembang Anak di Bogor dan Depok. Jurn. Media Gizi \& Keluarga, 32(1): 42-55

Hill, C., Stafford, R.F.P. (1974). Allocation of Time to Preschool Children and Educational Opportunity. The Journal of Human Resources, 9(3): 323-341.

Jones, C., Clark, L., Grusec, J., Hart, R., Plickert, G., Tepperman, L. (2002). Poverty, Social Capital, Parenting, and Child Outcomes in Canada [final report]. Canada (CA): Human Resource Development Canada Publication Center

Koentjaraningrat. (2007). Villages in Indonesia. $1^{\text {st }}$ Equinox Ed. Singapore (SG): Equinox Publishing

Leibowitz, A. (1982). Home Investment in Children. Schultz TW, editor. Chicago (US): University of Chicago Press

Maidah, R. (2014). Hubungan Alokasi Waktu Pengasuhan dan Pengasuhan Ibu dengan Kesejahteraan Anak Usia Sekolah pada Keluarga Petani [skripsi]. Bogor (ID): Institut Pertanian Bogor

Mardiya. (2013). Memahami faktor-faktor yang mempengaruhi tumbuh kembang anak. Di dalam: Topik-artikel website Pemerintah Kabupaten Kulon Progo, Daerah Istimewa Yogyakarta [internet]. [Waktu dan tempat pertemuan tidak diketahui]. Yogyakarta (ID): Bidang Advokasi Konseling dan Pembinaan KB dan Kesehatan Reproduksi pada BPMPDPKB Kabupaten Kulon progo. Hlm 1-6; [diunduh 2016 Mar 17]. Tersedia pada: http://www.kulonprogokab.go.id/v21/files/Memahami-faktor-faktor-yangmempengaruhi-tumbuh-kembang-anak.pdf

Mayer, S.E. (2002). The Influence of Parental Income on Children's Outcome. Wellington (NZ): Ministry of Social Development

Megawangi, R. (2004). Perspektif Holistik Peningkatan Kualitas Sumber Daya Manusia. Cimanggis (ID): Indonesia Heritage Foundation

Mincer, J., Polacheck, S. (1974). Family Investments in Human Capital: Earnings of Women. Di dalam: Schultz TW, Editor. Economics of The Family: Marriage, 
Children, and Human Capital. Chicago (US): University of Chicago. Hlm 397431

Myers, R.G. (1992). The Twelve Who Survive: Strengthening Programmes Of Early Childhood Development In The Third World. London (UK): Routledge

(1993). Toward a Fair Start for Children: Programming for Early Childhood Care and Development in the Developing World. Paris (FR): UNESCO

Purnama, D., Raksanagara, A.S., Arisanti, N. (2012). Hubungan Perilaku Ibu dalam Pemberian Makan dan Pengasuhan dengan Status Gizi Anak Balita Di Kecamatan Sukaresmi Kabupaten Garut. Bandung (ID): Universitas Padjajaran

Puspitawati, H. (2012). Gender dan Keluarga: konsep dan realita di Indonesia. Bogor (ID): IPB Press.

Puspitawati, H., Herawati, T.. (2013). Metode Penelitian Keluarga. Bogor (ID): IPB Press.

Rahmiati, Puspitawati, H. (2013). Hubungan antara invetasi dan kualitas anak usia sekolah pada keluarga petani. Jur. Ilm. Kel. \& Kons. 6(3):154-162

Salimar, Hastuti, D., Latifah, M. (2011). Pengaruh Beban Kerja, Pengetahuan, dan Status Gizi Ibu terhadap Pengasuhan dan Tumbuh Kembang Anak Balita pada Keluarga Miskin. Jurn. Penelitian Gizi dan Makanan 34(1): 39-49

Soetjiningsih. (1995. Tumbuh kembang anak. Ranuh, G., editor. Jakarta, ID: Buku Kedokteran EGC.

Sunarti, E. (2004). Mengasuh dengan Hati: Tantangan yang menyenangkan. Jakarta (ID): Elex Media Komputindo

Surachman, A., Hartoyo. (2012). Born to be destitute: capital transfer and intergenerational transfer of poverty. Undergraduate Research Journal for the Human Science, URJH, 11. Diambil dari http//www.kon.org/urc/v11/surachman.html. . (2015. Parental Investment and Poverty Dinamics in West Java, Indonesia. J Fam Econ. 36:340. Doi: 10.1007/s10834-015-9454-3

Susetyaningsih, A. (2012). Pengaturan Penggunaan Lahan Di Daerah Hulu DAS Cimanuk Sebagai Upaya Optimalisasi Pemanfaatan Sumberdaya Air. Jurn. Konstr. STT Garut 10(1): 1-8

Tangdilintin. P. (2008). Pembinaan Generasi Muda. Yogjakarta (ID): PT. Kanisius.

Todaro. M.P., Smith, S.C. (2006). Pembangunan ekonomi Jilid 1. Edisi ke-9. Munandar, P., penerjemah; Baranadi, D., Saat, S., \& Hardani, W., (Ed.). Jakarta, ID: PT Gelora Aksara Pratama. Terjemahan dari: Economic Development. 